\title{
EFFECT OF HEAT PRETREATMENTS ON CHEMICAL AND ANTIOXIDANT PROPERTIES OF MELON MANIS TERENGGANU (Cucumis melo var. Inodorus cv. Manis Terengganu 1) SEED OIL
}

\author{
AMIZA MAT AMIN*, NUR IZZATI MAT ROSDI, NOR HAYATI IBRAHIM and \\ TENGKU ROZAINA TENGKU MOHAMAD \\ Faculty of Fisheries and Food Science, Universiti Malaysia Terengganu, \\ 21030 Kuala Nerus, Terengganu, Malaysia \\ *E-mail: ama@umt.edu.my
}

Accepted 16 May 2020, Published online 30 June 2020

\begin{abstract}
The main objective of this study was to determine effect of different heat pretreatments on chemical and antioxidant properties of Melon Manis Terengganu (MMT) seed oil. The seeds were treated with four different heat pretreatment which were untreated (control), roasting, steaming and microwaving. Then the MMT seed oil was extracted from each treated seed using conventional extraction method. The chemical tests determined on the MMT seed oil were free fatty acid (FFA), iodine value (IV), saponification value and fatty acid composition. The antioxidant properties for MMT seed oil evaluated was total phenolic content (TPC), 1,1- diphenyl-2-picrylhdrazyl (DPPH) scavenging capacity and Ferric reducing antioxidant power (FRAP). It was found that different heat pretreatments of MMT seed significantly $(\mathrm{p}<0.05)$ affected the oil yield $(11.10-15.40 \%$.), free fatty acid value (3.55-5.04\%), DPPH radical scavenging activity (43.06-56.08\%), total phenolic content $(0.088-0.142$ $\mathrm{mg} \mathrm{GAE} / \mathrm{g})$ and FRAP activity $(0.0723-0.110 \mathrm{mmole} / 100 \mathrm{~mL})$. However, the seed heat pretreatment did not affect the fatty acid composition significantly $(\mathrm{p}<0.05)$. As for iodine value, it was different between untreated seed $\left(107.89 \mathrm{~g} \mathrm{I}_{2} / 100 \mathrm{~g}\right)$ and steamed seed $\left(104.41 \mathrm{~g} \mathrm{I}_{2} / 100 \mathrm{~g}\right)$ only $(\mathrm{p}<0.05)$.
\end{abstract}

Key words: Heat pretreatment, seed, oil, Melon Manis Terengganu, antioxidant

\section{INTRODUCTION}

Melon Manis Terengganu (Cucumis melo var. Inodorus cv. Manis Terengganu 1) is one of the melon species (Muhammad et al., 2018), with smooth yellow peel and orange in colour with orange coloured flesh. Melon has good taste and it contains carbohydrates, vitamin A, C, D, K, B and E, folic acid, carotene, minerals (potassium, magnesium, phosphorus, sodium, selenium, and calcium), and various aromatic compounds (Ivanova, 2012). Until now, only few studies have been reported on MMT including the effect of different storage temperatures on physicochemical characteristics and quality of MMT (Aishah Athirah et al., 2017) and effect of drying temperature and extraction solvents on antioxidant properties of immature MMT (Muhammad et al., 2018).

\footnotetext{
* To whom correspondence should be addressed.
}

The processing of fruits has generated large quantity of by-product such as seed, seed kernel and the skin, which is usually discarded (Mallek-Ayadi et al., 2018). Moreover, the high costs of drying, storage and transportation of these by-products are economically unprofitable. However, in recent years, fruit seeds have received growing interest due to the important nutritional and medicinal properties of their bioactive compounds. Many researches have reported on the nutritional benefits of melon seed and seed kernel. Milind and Kulwant (2011) reported that seed kernel is commonly used in renal disorders such as kidney, bladder stone, and inflammation of the liver. According Górnaś and Rudzińska (2016), fruit seed can be extracted to produce seed oil which contains a great number of valuable bio-component and natural antioxidants. A study on three varieties of melon cultivated in Bulgaria found that the seeds were rich in oil (30$50 \%$ ) and protein (12.0-35.0\%) (Petkova \& Antova, 2015). Honeydew melon seed oil was reported to be 
rich in biologically active substances such as tocopherols, sterols and phospholipid which give beneficial effect on humans (Zeb, 2016). Yanty et al. (2008) reported that honeydew melon seed possess medicinal properties and can be used as an anti-diabetic or acute eczema. Many studies have been reported on properties of seed oil such as from honeydew, bitter melon, sesame, soy, water melon, papaya, corn, egusi melon and pumpkin (Cucurbita pepo) (Petkova \& Antova, 2015; Peiretti et al., 2017; Olubi et al., 2019).

One of the important parameter in edible oil production is the quality of seed oil. Pretreatment is one of the factors that can affect the yield and quality of seed oil. Roasting, microwaving, and steaming are commonly used heat pretreatments in edible oil industry. These heat pretreatments were reported to affect the quality, stability, and antioxidant properties of oil extraction from plant seed (Uquiche et al., 2008; Durdevic et al., 2017; Gumaling et al., 2018; Petkova \& Antova, 2019). According to Uquiche et al. (2008), microwaving pretreatment resulting in higher oil yield and gave oil with high stability towards oxidative deterioration compared to untreated seed because microwave pretreatment can rupture the cell wall and enable the oil to move through permeable cell wall. However, Danso-Baoteng (2011) found that the steaming pretreatment yield the highest amount of sunflower seed oil. On the other hand, Potočnik et al. (2018) reported that iodine value decreased as roasting temperature rose. Drużyńska et al. (2007) reported that the values of antioxidant not only depend on the type of the solvent used but it also depends on parameters exerted by the solvent that were used for extraction. Besides that, the component that is present in seed oil, when heated can causes a decrease in antioxidant activity (Abril et al., 2019). Durmaz and Gökmen (2011) stated that the antioxidant activities increased with roasting pretreatment due to the formation of Mailard reaction products. Previous studies have been reported on the effect of heat pretreatment on yield and properties of seed oil including from grape seed (Oomah et al., 1998), African pear seed (Onyeka et al., 2005), cashew nut (Chandrasekara \& Shahidi, 2012), honeydew seed (Zhao et al., 2012), sky fruit seed (Lau et al., 2012; Gumaling et al., 2018) and pomegranate seed (Đurđević et al., 2017). However, no study has been reported on the effect of heat pretreatments on the properties of MMT seed oil. Thus, this study aimed to determine the effects of different heat pretreatment on the oil yield as well as chemical and antioxidant properties of MMT seed oil.

\section{MATERIALS AND METHODS}

\section{Materials}

Fresh Melon Manis Terengganu (MMT) seeds were obtained from a MMT supplier in Batu Hampar, Manir, Terengganu and it was stored in a freezer until further use. Acetic acid, diethyl ether, Wjis solution, 2, 2-diphenyl-1-picrylhydrazyl reagent and, gallic acid were purchased from Sigma-Aldrich Sdn Bhd. All other chemicals and reagents used were of analytical grades.

\section{Methods}

\section{Sample preparation}

Melon Manis Terengganu (MMT) seeds were cleaned using tap water and then divided into four portions for 4 types of heat pretreatment. For untreated (control) sample, MMT seeds were dried at room temperature $\left(30^{\circ} \mathrm{C}\right)$ under the fan for 24 hours. For roasting heat pretreatment, the seeds were roasted using a convection oven (Master 450, Garland Freeland, Pennsylvania) at $200^{\circ} \mathrm{C}$ for 20 min. For steaming heat pretreatment, the seeds were steamed at $100^{\circ} \mathrm{C}$ for $20 \mathrm{~min}$. For microwaving heat pretreatment, the seeds were microwaved using a microwave (Dimension 4, The Genius National, Japan) at $2450 \mathrm{mHz}$ for $15 \mathrm{~min}$.

\section{Extraction of oil}

Extraction of oil from untreated (control) and treated (roasting, steamed and microwaved) samples of MMT seeds were carried out according to modified Blight and Dyer (1959) method. For each control and treated samples, $100 \mathrm{~g}$ of MMT seed was mixed with $200 \mathrm{ml}$ methanol and $100 \mathrm{ml}$ chloroform. Then, the mixture was homogenized using a Waring blender (Waring, USA). The mixture was filtered to separate the seeds and the solvent. Next, the same amount of methanol solvent $(200 \mathrm{ml})$ and chloroform solvent $(100 \mathrm{ml})$ were mixed with the filtered residue. After that, the mixture was transferred into a blue-capped bottle and agitated using an incubator shaker (Innova 40R, USA) at rpm 200 at $25^{\circ} \mathrm{C}$ for an hour. After the agitation process, the mixture was filtered to separate the seed residue and the solvent. The agitation and the filtering process were consistently conducted until a clear solvent was obtained. The solvent was then evaporated using a rotary evaporator (N-1000 Eyela, Japan) at 65 until almost all solvent was evaporated. The resulting seed oil was centrifuged in a centrifuge (Hettich Zentrifugen Universal 320 , Germany) at $4000 \mathrm{rpm}$ for $10 \mathrm{~min}$. Finally, the supernatant was stored at -20 prior to further analysis (Yanty et al., 2008). 


\section{Chemical properties of MMT seed oil}

\section{Free fatty acid}

Determination of free fatty acid (FFA) was conducted according to AOAC (1980) method. One gram of oil was dissolved with $25 \mathrm{ml}$ diethyl ether dissolved with $25 \mathrm{ml}$ of alcohol and $1 \mathrm{ml}$ of $1 \%$ phenolphthalein solution. The solution was then titrated with aqueous $0.1 \mathrm{M}$ of sodium hydroxide solution by shaking continuously until pink colour solution formed. The amount of aqueous $0.1 \mathrm{M}$ of sodium hydroxide solution used was recorded. The percentage of FFA was calculated as follows:

FFA (as \% oleic acid) $=\frac{\begin{array}{c}\text { volume of titration } x \\ \text { normality of } \mathrm{NaOH} \times 28.2\end{array}}{\text { weight of oil }(\mathrm{g})}$

\section{Iodine value}

Iodine value of the MMT oils was measured according to AOAC (2000) method. Oil sample $(0.2 \mathrm{~g})$ was weighed in a $250 \mathrm{ml}$ conical flask. Then, $20 \mathrm{ml}$ of cyclohexane was added and swirled until the oil was completely dissolved. Next, $25 \mathrm{ml}$ of Wijs solution was added into the mixture. The mixture was kept in the dark for one hour. Then, $20 \mathrm{ml}$ of $15 \%$ potassium iodide was added into the flask followed by $100 \mathrm{ml}$ distilled water. The starch indicator was added and the mixture was titrated with $0.1 \mathrm{~N}$ sodium thiosulphate till colourless end point. The blank sample was conducted without the sample. The iodine value was calculated as follows:

$$
\text { Iodine value }(\mathrm{IV})=\frac{(B-S) \times N \times 12.69}{\text { weight of oil }(g)}
$$

\section{Saponification value}

Saponification value of the MMT oils was measured according to AOAC (2000) method. The oil sample $(2 \mathrm{~g})$ was weighed in a conical flask. Next, $25 \mathrm{ml}$ alcoholic potassium hydroxide was added. The mixture was then heated in boiling water using a water bath (TE-10D Temp., Techne, UK) at $100^{\circ} \mathrm{C}$ for 1 hour. Then, $1 \mathrm{ml}$ of phenolphthalein solution was added and the solution, and was titrated with hot excess alkali of $0.5 \mathrm{M}$ hydrochloric acid. The saponification value was calculated as follows:

$$
\begin{gathered}
\text { Saponification value }=\mathrm{mg} \text { of } \mathrm{KOH} \text { consumed by } \\
1 \mathrm{~g} \text { of oil } \\
\text { Weight of } \mathrm{KOH}=(28.05 \mathrm{x} \text { volume of } \mathrm{KOH}) / \\
\text { sample weight }(\mathrm{g})
\end{gathered}
$$

Volume of $\mathrm{KOH}$ consumed by $1 \mathrm{~g}$ oil $=[$ Blank test] $\mathrm{ml}$

\section{Peroxide value}

Analysis of peroxide value was conducted according to AOAC (2000). The oil sample ( $1 \mathrm{~g}$ ) was placed in a $250 \mathrm{ml}$ conical flask and then dissolved with $10 \mathrm{ml}$ of chloroform and $15 \mathrm{ml}$ acetic acid at a ratio of $2: 3$. Then, $1 \mathrm{ml}$ of concentrated potassium iodide was added and kept in the dark for $5 \mathrm{~min}$. After $5 \mathrm{~min}, 75 \mathrm{ml}$ of distilled water was added. Next, $1 \mathrm{ml}$ of $2 \%$ starch indicator was added and the mixture was titrated with $0.01 \mathrm{~N}$ sodium thiosulphate until the colourless end point was attained. The blank sample was conducted without the sample. The peroxide value (PV) was calculated as follows:

$$
\mathrm{PV}=\frac{\begin{array}{c}
\text { volume of titration in } \mathrm{ml}(\text { sample-blank) } \times \\
\text { (normality of } \left.\mathrm{Na}_{2} \mathrm{~S}_{2} \mathrm{O}_{3} \times 1000\right)
\end{array}}{\text { weight of oil }(\mathrm{g})}
$$

\section{Fatty acid composition}

Esterification of fatty acid methyl ester (FAME) was carried out according to Timms (1978). Oil sample $(0.5 \mathrm{~g})$ was weighed in a $5 \mathrm{ml}$ vial and mixed with $1 \mathrm{ml}$ hexane and $0.2 \mathrm{ml}$ of sodium methoxide using a vortex (MS1 Minishaker, IKA Works, Guangzhou) for $1 \mathrm{~min}$. The mixture was allowed to separate into two layers and the upper layer was pipetted into $2 \mathrm{ml}$ vial.

Analysis of fatty acids was conducted using gas chromatography (Shidmadzu GC-2010, Japan) equipped with flame ionization detector (FID) and BPX-70 column (30 m length $x 0.25 \mathrm{~mm}$ internal diameter $\times 0.2 \mathrm{~m}$ film thickness). The flow rate of the carrier gas (helium) was $1 \mathrm{ml} / \mathrm{min}$ and the split ratio was $1: 10$. The injector and detector temperatures were $230^{\circ} \mathrm{C}$ and $250^{\circ} \mathrm{C}$, respectively. The oven temperature was programmed initially at $70^{\circ} \mathrm{C}$, holding for $5 \mathrm{~min}$, and increased to $140^{\circ} \mathrm{C}$ at $10^{\circ} \mathrm{C} / \mathrm{min}$, then held isothermal for $5 \mathrm{~min}$. The temperature was increased from $140^{\circ} \mathrm{C}$ to $240^{\circ} \mathrm{C}$ at $4^{\circ} \mathrm{C} / \mathrm{min}$ and held for $1 \mathrm{~min}$. A 37 components of fatty acid methyl esters mix (Sigma, St. Louis, Missouri, USA) was used as external standard for peak identification.

\section{Antioxidant properties of MMT seed oil}

\section{Total phenolic content}

Oil sample $(0.5 \mathrm{ml})$ was mixed with $2 \mathrm{ml}$ of $10 \%$ of diluted Folin-Ciocalteau reagent. The solution was kept for $5 \mathrm{~min}$ and $1.6 \mathrm{ml}$ of $7.5 \%$ of sodium carbonate was added. The solution was vortexed and was kept in room temperature $\left(25^{\circ} \mathrm{C}\right)$ for $60 \mathrm{~min}$. The absorbances were measured at 765 $\mathrm{nm}$ using a UV-spectophotometer against methanol blank (Gutfinger, 1981). 


\section{DPPH radical scavenging activity}

Oil sample $(3 \mathrm{ml})$ in methanol $(300 \mathrm{mg} / \mathrm{ml})$ was mixed with $3 \mathrm{ml}$ of methanolic solution that contained DPPH radical $(0.2 \mathrm{mM})$. The mixture was vortexed (IKA Works, Guangzhou) for $1 \mathrm{~min}$ at $2000 \mathrm{rpm}$ and allowed to stand for $30 \mathrm{~min}$ in the dark. Next, the absorbance was read against blank using a spectrophotometer (GENEYS 20 Thermospectronic, Thermo Electron Corp., USA) at $517 \mathrm{~nm}$. Percentage of DPPH inhibition activity (\%) was calculated as described by Shimada et al. (1992):

$\begin{aligned} & \text { Percentage inhibition } \\ & \text { activity }(\%)\end{aligned}=\frac{\begin{array}{l}\text { Absorbance of control }- \\ \text { absorbance of sample }\end{array}}{\text { absorbance of control }} \times 100$

\section{Ferric reducing antioxidant power (FRAP)}

The ferric reducing antioxidant power (FRAP) reagent was prepared from $300 \mathrm{mM}$ sodium acetate buffer ( $\mathrm{pH} 3.6), 10 \mathrm{mM} \mathrm{2,4,6-tripyridyl-S-triazine}$ (TPTZ) solution in $40 \mathrm{mM} \mathrm{HCl}$ and $20 \mathrm{mM}$ ferric chloride solution in a proportion of 10:1:1 ( $/ \mathrm{v} / \mathrm{v})$. An aliquot of $400 \mathrm{~L}$ of the diluted sample was mixed with $3.6 \mathrm{ml}$ of FRAP reagent. Then, the mixture was kept in the water bath (TE-10D Temp., Techne, UK) at 37 for $10 \mathrm{~min}$. The absorbance was measured at $593 \mathrm{~nm}$ using a UV-VIS spectrophotometer. The standard curve was elaborated at 10 concentration levels of iron sulphate according to Muhammad et al. (2018).

\section{Statistical analysis}

All analyses were carried out in triplicate $(n=3)$. Data were presented as mean standard deviation. The significance difference between means were determined by a Tukey's Multiple Comparison test following a one-way analysis of variance (ANOVA) at a significance level of $p<0.05$ using a Minitab software Version 16 (Minitab Inc., USA).

\section{RESULTS AND DISCUSSION}

\section{Effect of heat pretreatment on yield of extracted oil from MMT seed}

Table 1 shows the oil yield, free fatty acid content, iodine value, saponification value and peroxide value MMT seed oil obtained from different heat pretreatments. The oil yield ranged from 11.10 to $15.40 \%$. There was a significant difference in the oil yield of MMT seeds with different heat pretreatment ( $\mathrm{p} 0.05)$, except for microwaving and roasting heat pretreatment. The highest oil yield was obtained from microwaving, followed by roasting and steaming, and finally untreated MMT seed.

The oil yields in the present study were similar to that of grape seed (13.9-14.8\%; Oomah et al., $1998)$ and African pear seed (2.74-13.21\%; Onyeka et al., 2005), but higher than that of corn (3.1-5.7\%; O' Brien, 2004). However, the yield of MMT seed oils in the present study were lower compared to honeydew and hybrid 1 (41.6\%; Petkova \& Antova, 2015), Dessert 5 (44.5\%; Petkova \& Antova, 2015), agrestis melon (23.3\%; Mariod et al., 2009), Kalahari melon (30.5\%; Nyam et al., 2009a), bitter melon (19.3\%; Mariod et al., 2009), watermelon (50\%; Baboli \& Kordi, 2010), pumpkin (31.9$39.44 \%$; Yanty et al., 2008), soy (18-22\%; O' Brien, 2004), rapeseed (41\%; Yang et al., 2014), corn (1820\%; Petkova \& Antova, 2015) and sunflower (40\%; Petkova \& Antova, 2015).

In the present study, the oil yield of roasted MMT was higher than the untreated MMT seed. A similar finding was reported for African pear seed (Onyeka et al., 2005), cashew nut (Chandrasekara $\&$ Shahidi, 2012) and honeydew seed (Zhao et al., 2012). Meanwhile, Oomah et al. (1998) reported that the oil yield of microwaved grape seed was higher than the untreated grape seed. A different finding was reported by Lau et al. (2012) on sky fruit seed where the oil yields obtained from microwave

Table 1. Chemical properties of Melon Manis Terengganu seed oil as affected by different heat pretreatments of seeds

\begin{tabular}{|c|c|c|c|c|c|}
\hline $\begin{array}{l}\text { Heat } \\
\text { pretreatment }\end{array}$ & $\begin{array}{l}\text { Oil Yield } \\
\qquad \%)\end{array}$ & $\begin{array}{l}\text { Free fatty acid } \\
\text { (\% oleic acid) }\end{array}$ & $\begin{array}{l}\text { lodine value } \\
\left(\mathrm{g} \mathrm{I}_{2} / 100 \mathrm{~g}\right)\end{array}$ & $\begin{array}{l}\text { Saponification value } \\
\quad\left(\mathrm{mg} \mathrm{KOH} \mathrm{g}^{-1}\right)\end{array}$ & $\begin{array}{c}\text { Peroxide value } \\
\left(\mathrm{meqO}_{2} / \mathrm{kg}\right)\end{array}$ \\
\hline Untreated & $11.10 \pm 0.63^{c}$ & $4.48 \pm 0.12^{c}$ & $107.89 \pm 1.73^{a}$ & $171.32 \pm 1.16^{b}$ & $12.79 \pm 0.75^{c}$ \\
\hline Microwaving & $15.40 \pm 0.34^{a}$ & $3.55 \pm 0.19^{d}$ & $105.60 \pm 1.77^{a b}$ & $163.83 \pm 1.72^{c}$ & $13.70 \pm 0.55^{b}$ \\
\hline Roasting & $14.84 \pm 0.86^{a}$ & $4.83 \pm 0.097^{b}$ & $106.62 \pm 0.6^{a b}$ & $185.19 \pm 1.87^{a}$ & $14.57 \pm 0.26^{a}$ \\
\hline Steaming & $12.13 \pm 0.98^{b}$ & $5.04 \pm 0.057^{a}$ & $1074.41 \pm 0.56^{b}$ & $165.71 \pm 1.17^{c}$ & $11.52 \pm 0.47^{d}$ \\
\hline
\end{tabular}

Values are mean standard deviation from three replications $(n=3)$.

Values with different superscript letter in the same column are significantly different at $p 0.05$ 
and untreated seeds were higher (28.46-29.5\%) compared to roasting and steaming (23.29-24.82\%) samples. The variations in oil yields in these studies may be contributed to differences in plant cultivar, cultivation climate, ripening/maturity stage and the oil extraction method used (Nyam et al., 2009b; Petkova \& Antova, 2015).

In general, higher oil yields were obtained from microwaved or roasted seeds. This probably was due to damage of cell membrane at high temperature during heat pretreatment, which increased the yield of seed oil extraction (Chandrasekara \& Shahidi, 2012). According to Zhong et al. (2018), microwave is an efficient means for accelerating solvent extraction from plant matrices and it requires less solvent. Microwave penetrates to the seed oil due to the convection from electromagnetic energy to thermal energy. The cell membrane was ruptured by microwave radiation and created permanent pores and allowed easier oil extraction (Mazaheri et al., 2019). Ramanadhan (2005) stated that microwave heat for oil extraction has many advantages compared to conventional methods. For example, improvement of extracted oil yield and quality, direct extraction capability, lower energy consumption, faster processing time and reduced solvent contents. On the other hand, roasting heat pretreatment can produce condiment oils and extensive processing method that can increase the availability of nutrients and inactive enzymes. According Mazaheri et al. (2019), desired flavours, colours and promoting palatability of oil can be achieved from roasting heat pretreatment.

\section{Effect of heat pretreatments on chemical properties of MMT seed oil}

\section{Free fatty acid content}

Free fatty acid (FFA) is the one of the parameters to monitor the quality of edible oil. The FFA content of MMT seed oils extracted from different heat pretreatments in the present study ranged from $3.55 \%$ to $5.04 \%$. There was a significant difference in FFA content of MMT seed oils between all different heat pretreatments $(p<0.05)$. The highest FFA content was found in the MMT seed oil extracted from steamed $(5.04 \%)$, followed by roasted $(4.83 \%)$, untreated $(4.48 \%)$ and microwaved $(3.55 \%)$ seeds.

The FFA content of MMT seed oils in the present study were higher than Cucumis melo Maazoun cultivar (0.31\%), honeydew melon (2.5\%), watermelon (1.41\%), pumpkin (1.44\%) (MallekAyyadi et al., 2019), oriental melon (2.54\%; Chen et al., 2014) and honeydew melon (2.5\%; Yanty et al., 2008) seed oils. This finding indicated that MMT seed oils in the present study were more susceptible to lipolysis. Lipolysis process is caused by water content and lipase enzymes in the seed. Lipase enzyme in the oil will accelerate the hydrolysis process (Lau et al., 2012). According to Japir et al. (2017), an increase in the FFA content in crude palm oil was due to the lipolysis by lipase enzyme. They also stated that FFA content is very important to determine quality index for the length of the storage, marketing and production of palm oil products. The breakdown of triglyceride and the release of FFA are usually due to evolving climate, torrential rainfall, humidity and unsuitable storage condition (Japir, 2017).

Onyeka et al. (2005) reported that the FFA contents in the roasted and steamed African black pear seeds were higher than untreated seed due to greater liberation of FFA. However, for sky fruit seed oil, no significance difference was reported between untreated sky fruit seed with other heat pretreatments (1.48-1.85\%) (Lau et al., 2012).

\section{Iodine content}

Iodine value (IV) is a measure of degree of unsaturation of oil, solidification temperature and oxidation stability. The higher the unsaturation, the higher the iodine value and the higher the susceptibility to oxidation. The IV of extracted MMT seed oils in the present study ranged from 104.41 to $107.89 \mathrm{~g} \mathrm{I}_{2} / 100 \mathrm{~g}$. This study showed that the IV of the MMT seed oils were lower than Kalahari melon (125.0 g I $/ 100 \mathrm{~g}$; Nyam et al., 2009a), Cucumis melo Maazoun cultivar (139.5 g $\mathrm{I}_{2} / 100 \mathrm{~g}$; Mallek-Ayadi et al., 2019), honey dew (153.4 g I $/ 100 \mathrm{~g})$, water melon $\left(156 \mathrm{~g} \mathrm{I}_{2} / 100 \mathrm{~g}\right.$; Yanty et al., 2008), sunflower $\left(137 \mathrm{I}_{2} / 100 \mathrm{~g}\right.$; Yanty et al., 2008) and soy $\left(131 \mathrm{I}_{2} / 100 \mathrm{~g}\right.$; Yanty et al., 2008) seed oils.

A lower IV of MMT seed oils indicated a lower degree of unsaturation and lower melting point than the above-mentioned seed oils. A higher IV was found in the untreated MMT seed oil compared to steamed seed oil $(\mathrm{p}<0.05)$. Similar finding was reported by Potočnik et al. (2018) where IV gradually decreased with increasing heating power setting and time. Meanwhile, the IV of the roasted and microwaved MMT seed oils were not significantly different from other heat pretreatments ( $p>0.05)$. However, Yanty et al. (2008) reported a contrasting finding whereby the microwaved and roasted honeydew seed oils gave significant reduction in IV due to formation of polar compound when heating. The reduction in IV during heating were often taken as a measure of lipid oxidation because high temperature accelerates lipid oxidation the number of unsaturation sites reduced as a result of oxidation, polymerization, or breakage of the long-chain fatty acid (Anjum et al., 2006). 


\section{Saponification value}

Saponification was defined as the number of $\mathrm{mg}$ of potassium hydroxide $(\mathrm{KOH})$ necessary to saponify $1 \mathrm{~g}$ of lipid sample. The saponification value of MMT seed oils in the present study ranged from 163.83 to $185.19 \mathrm{mg} \mathrm{KOH} \mathrm{g}^{-1}$. There was a significant difference in saponification value of MMT seed oils for all heat pretreatments $(p<0.05)$ except between microwaved seeds and steamed seeds. The highest saponification value found in the roasted MMT seeds, followed by untreated, steaming and microwaved seeds.

The saponification values of MMT seed oils were in similar range with Kalahari melon (173.2 mg $\left.\mathrm{KOH} \mathrm{g}^{-1}\right)$, kenaf $\left(171.0 \mathrm{mg} \mathrm{KOH} \mathrm{g}{ }^{-1}\right)$, pumpkin (185.3 $\left.\mathrm{mg} \mathrm{KOH} \mathrm{g}^{-1}\right)$, roselle $\left(172.3 \mathrm{mg} \mathrm{KOH} \mathrm{g}^{-1}\right)$ and Suaeda salsa L (174.24 mg KOH g $\left.{ }^{-1}\right)$ seed oils (Nyam et al., 2009a; Baogu et al., 2013). A lower saponification value was reported for Cucumis melo var Maazoun cultivar (139.8 mg KOH g ${ }^{-1}$; MallekAyadi et al., 2019). On the other hand, a higher saponification values were reported for bitter melon (190.7 mg KOH g-1), Cucumis melo hybrid AF-522 (210.62 $\mathrm{mg} \mathrm{KOH} \mathrm{g}^{-1}$ ), honeydew melon (210.2 mg $\mathrm{KOH} \mathrm{g}^{-1}$ ) and Cucumis melo var saccharinus (191.4 mg KOH g ${ }^{-1}$ ) seed oils (Yanty et al., 2008; Nyam et al., 2009b; Baogu et al., 2013).

A higher saponification value indicates the presence of low content of long chain fatty acid, making it suitable as edible oil. A higher saponification value of oil was useful in the production of liquid soap and shampoos because it contains more of the unsaturated fatty acids and indicates greater liquidity (Lau et al., 2012). The saponification values of MMT seed oils with different heat pretreatment were within the range for certain crude vegetables oil like corn oil (187$197 \mathrm{mg} \mathrm{KOH} \mathrm{g}^{-1}$ ) and mustard oil (170-184 mg $\mathrm{KOH} \mathrm{g}^{-1}$ ) (Codex Alimentarius Commission, 2001).

\section{Peroxide value}

Peroxide value (PV) is defined as the milliequivalent $(\mathrm{mEq})$ of peroxide per kilogram of fat or oil and it is an indicator of the initial stage of lipid oxidation. The PVs of MMT seed oils in the present study ranged from 11.52 to $14.57 \mathrm{mEqO}_{2} /$ $\mathrm{kg}$. The PV of MMT seed oils were higher than bitter melon, Kalahari melon, kenaf, pumpkin and roselle (1.5-6.5 $\mathrm{mEq} \mathrm{O} / \mathrm{kg}$; Nyam et al., 2009a), watermelon (3.24 mEq $\mathrm{O}_{2} / \mathrm{kg}$ oil; Baboli \& Kordi, 2010) and sky fruit $\left(1.98-3.25 \mathrm{mEq} \mathrm{O}_{2} / \mathrm{kg}\right.$; Lau et $a l ., 2012)$ seed oils. The PVs of MMT seed oil in the present study were lower than $15 \mathrm{mEqO}_{2} / \mathrm{kg}$, which nearly reached the Codex limit for virgin oil (Codex Alimentarius Commission, 2001). These findings indicated that the MMT seed oil were unstable and susceptible to rancidity. Moussata and Akoh (1998) also reported that the stability of melon seed was low compared to other seeds because it was rich in linoleic acid (64.5\%).

The PVs of MMT seed oils were significantly different for all heat pretreatments $(p<0.05)$. The highest PV was found in roasted followed by microwaved, untreated and finally steamed MMT seed oils. This finding shows that the oils extracted from heat treated MMT seeds contained higher peroxide values than untreated seed, except for steamed seed. Similar findings were reported by Lau et al. (2012) whereby the roasted sky fruit seed had highest value of peroxide $\left(3.25 \mathrm{mEqO}_{2} / \mathrm{kg}\right)$ and followed by microwaved $\left(2.96 \mathrm{mEqO}_{2} / \mathrm{kg}\right)$, untreated $\left(2.61 \mathrm{mEqO}_{2} / \mathrm{kg}\right)$ and steamed sky fruit seed oil $\left(1.98 \mathrm{mEqO}_{2} / \mathrm{kg}\right)$. Similar finding also has been reported in roasted pumpkin oil (Potočnik et al., 2018). A high PV in roasted seed is due to the damaged of the structure of lipid storage cell (Lau et al., 2012). However, Lee et al. (2004) reported a decrease in PV of roasting safflower oil due to the non-enzymatic reaction and caramelization product formed during roasting.

The microwaved MMT seed oil also had higher PV compared to the untreated MMT seed oil. This finding is in agreement Lau et al. (2012) where the PV of microwaved sky fruit seed oil was also higher (2.96 $\mathrm{mEq} \mathrm{O} \mathrm{O}_{2} / \mathrm{kg}$ ) compared to the untreated seed oil (2.61 $\mathrm{mEq} \mathrm{O} / 2 / \mathrm{kg}$ ). Microwaved grape seed oil (Oomah et al., 1998) also gave similar trend. This is because of the reactive radicals formed during exposure of the seed to microwave energy (Uquiche et al., 2008).

\section{Fatty acid composition}

Table 2 shows no significant difference between all MMT seed oils in the present study $(\mathrm{p}>0.05)$. Fatty acid composition of MMT seed oils comprised of linoleic acid (60.85-60.89\%), oleic acid (20.85$20.89 \%$ ), palmitic acid (17.72-17.83\%), cis-11eicosanoic acid or gondoic acid $(0.430-0.439 \%)$ and myristic acid (0.06-0.069\%). Similar findings were reported by Silva et al. (2014), for melon seed oil where linoleic acid was the main fatty acid (52$69 \%$ ), followed by oleic acid (12-32\%) and palmitic acid (9-24\%). Mallek-Ayadi et al. (2019) also reported the dominant fatty acids in Cucumis melo, Maazoun cultivar seed oil were linoleic acid $(68.98 \%)$, oleic acid (15.84\%) and palmitic acid $(8.76 \%)$. A high content of linoleic acid may have favourable nutritional implications and beneficial physiological effect in the prevention of coronary heart disease and cancer (Oomah et al., 2000).

The MMT seed oils in the present study contained $17.78-17.89 \%$ total saturated fatty acid, $21.28-21.325 \%$ monounsaturated fatty acid and $60.85-60.89 \%$ polyunsaturated fatty acid. The ratio of unsaturated fatty acid to saturated fatty acid for MMT seed oils ranged from 3.75 to 4.06. A high 
Table 2. Fatty acid composition of Melon Manis Terengganu seed oil as affected by different heat pretreatments of seeds (\%)

\begin{tabular}{|c|c|c|c|c|}
\hline Heat pretreatment & Untreated & Microwaving & Roasting & Steaming \\
\hline Myristic acid C14:0 & $0.06 \pm 0.02$ & $0.069 \pm 0.01$ & $0.064 \pm 0.05$ & $0.060 \pm 0.01$ \\
\hline Palmitic acid C16:0 & $17.74 \pm 0.09$ & $17.78 \pm 0.04$ & $17.83 \pm 0.021$ & $17.72 \pm 0.05$ \\
\hline Oleic acid C18:1 & $20.87 \pm 0.01$ & $20.85 \pm 0.06$ & $20.85 \pm 0.02$ & $20.89 \pm 0.05$ \\
\hline Linoleic acid C18:2 & $60.89 \pm 0.021$ & $60.87 \pm 0.02$ & $60.85 \pm 0.04$ & $60.89 \pm 0.07$ \\
\hline Gondoic acid C20:1 & $0.439 \pm 0.02$ & $0.434 \pm 0.05$ & $0.430 \pm 0.02$ & $0.435 \pm 0.09$ \\
\hline Total saturated fatty acid & 17.8 & 17.85 & 17.89 & 17.78 \\
\hline MUFA & 21.31 & 21.28 & 21.28 & 21.325 \\
\hline Total unsaturated fatty acid & 72.26 & 69.87 & 67.14 & 71.56 \\
\hline Unsaturated FA / saturated FA & 4.06 & 3.91 & 3.75 & 4.02 \\
\hline
\end{tabular}

Table 3. Antioxidant activities of Melon Manis Terengganu seed oil as affected by different heat pretreatments of seeds

\begin{tabular}{lccc}
\hline Heat pretreatment & $\begin{array}{c}\text { DPPH free radical } \\
\text { scavenging activity }(\%)\end{array}$ & $\begin{array}{c}\text { Total Phenolic content } \\
(\mathrm{mg} \mathrm{GAE} / \mathrm{g})\end{array}$ & $\begin{array}{c}\text { Ferric reducing antioxidant power } \\
\left(\mathrm{mmol} F \mathrm{Fe}^{2+} / 100 \mathrm{ml}\right)\end{array}$ \\
\hline Untreated & $56.08 \pm 0.87^{\mathrm{a}}$ & $0.109 \pm 0.002^{\mathrm{c}}$ & $0.110 \pm 0.0047^{\mathrm{a}}$ \\
Microwaving & $45.95 \pm 0.76^{\mathrm{b}}$ & $0.135 \pm 0.003^{\mathrm{b}}$ & $0.0723 \pm 0.0047^{\mathrm{d}}$ \\
Roasting & $0.55^{\mathrm{c}}$ & $0.142 \pm 0.002^{\mathrm{a}}$ & $0.0803 \pm 0.0015^{\mathrm{c}}$ \\
Steaming & $54.64 \pm 0.49^{\mathrm{a}}$ & $0.088 \pm 0.002^{\mathrm{d}}$ & $0.0930 \pm 0.0036^{\mathrm{b}}$ \\
\hline
\end{tabular}

Values are mean \pm standard deviation from three replications $(n=3)$.

Values with different superscript letter in the same column are significantly different at $p<0.05$.

content of unsaturated fatty acid may lead to more lipid oxidation during storage as compared to saturated fatty acid. The ratio of unsaturated fatty acid to saturated fatty acid for Cucumis melo (Mazoun cultivar) seed oil (5.79) was higher than MMT seed oil (Mallek-Ayadi et al., 2019). Meanwhile, honeydew melon seed oil contained a lower PUFA (59.20\%) and total saturated fatty acid (15.70\%) and higher MUFA (25\%) (Górnaś \& Rudzińska, 2016) compared to the MMT seed oils.

According Silva et al. (2018), the fatty acid profile of melon seeds oil is very similar to soybean and sunflower oils, two of the most commonly used vegetable oils. It is also very analogous to grape seeds oil and paprika seeds oil, although grape seeds oil has a lower content of saturated fatty acids. Silva et al. (2018) also stated that the content of linoleic acid in melon seeds oil is very similar to blackcurrant and watermelon seeds oils.

\section{Effect of heat pretreatment on antioxidant properties of MMT seed oil}

\section{Total phenolic content}

Table 3 shows the antioxidant activities of Melon Manis Terengganu seed oil as affected by different heat pretreatments of seeds. Table 3 shows that there was a significant difference in total phenolic content (TPC) in the MMT seed oils for all heat pretreatments $(\mathrm{p}<0.05)$. Roasted MMT seed oil contained the highest TPC (0.142 mg GAE/g).
This finding is consistent with Mazaheri et al. (2019) where the roasted black seed oil contained a higher amount of caffeic acid (4812.77 mg caffeic $\mathrm{acid} / \mathrm{kg}$ of oil) compared to the unroasted seed (4527.90 $\mathrm{mg}$ caffeic acid $/ \mathrm{kg}$ of oil). The decreasing in caffeic content due to thermal decarboxylation occur during black seed heat pretreatment (Yang et al., 2014). The reduction of moisture content occurred when the seeds were roasted and the increase of total phenolic content (Azhari et al., 2014). This is because, denaturation of protein is linked to the phenolic compound which resulted in easier extraction (Yang et al., 2014).

The microwaved MMT seed oil also contained higher TPC (0.135 mg GAE/g) compared to untreated and steamed MMT seed oils. Similar findings were reported by Mazaheri et al. (2014), where the TPC of black seed oil increased from 3546.58 to 6889.02 (mg caffeic acid $/ \mathrm{kg}$ of oil) when the sample was heated by microwave. Mazaheri et al. (2014) stated that the increasing amount of microwave irradiation had a positive effect on the extraction of phenolic compound.

The total phenolic content for steamed MMT seed oil were the lowest which was only $0.088 \mathrm{mg}$ GAE/g. High temperature with long drying time could destroy the phenols and decreasing water presents. The antioxidant values were reduced because it associated with thermal degradation of phytochemicals, enzymatic degradation of phenolic compounds and loss of antioxidant enzymes 
activities (Nyam et al., 2009b). Total phenolic content of bitter melon ( $0.32 \mathrm{mg} \mathrm{GAE} / \mathrm{g})$, kalahari melon $(0.23 \mathrm{mg} \mathrm{GAE} / \mathrm{g})$ and kenaf $(0.24 \mathrm{mg}$ $\mathrm{GAE} / \mathrm{g}$ ) seed oils were higher compared to that of MMT in the present study.

\section{DPPH radical scavenging activity}

Table 3 shows that the untreated MMT seed oil (56.08\%) had the highest DPPH free radical scavenging activity, followed by steamed (54.64\%), microwaved (45.95\%) and roasted (43.06\%) MMT seed oils. This shows that the free radical scavenging capacities of microwaved and roasted MMT seed oil were significantly reduced due to heating process. Heating has resulted in release of phenolic compound from the cell wall that affects the bioaccessibility of total phenolics. Muhammad et al. (2018) reported a radical scavenging activity of melon seed oils extracted using different solvents extraction (methanol, ethanol and distilled water) ranging from $23.38 \%$ to $50.36 \%$.

\section{Ferric reducing antioxidant power (FRAP)}

Table 3 shows that MMT seed oil gave low FRAP activity $\left(0.0723-0.110 \mathrm{mmol} \mathrm{Fe}{ }^{2+} / 100 \mathrm{ml}\right)$. This study found that the highest FRAP activity was given by MMT seed oil from untreated $>$ steaming $>$ roasting $>$ microwaving. According to Abril et al. (2019), heating can cause a decreasing in antioxidant activity in the seed oil. However, Muhammad et al. (2018) reported that MMT sample that was dried at 60 exhibited the highest value of FRAP value $(49.30 \%)$ and similar with bitter guard melon. This is because polyphenol oxidase activity was fully activated at higher temperature (60 and thus the oxidation product from polyphenol oxidase contributed to the increased antioxidant capacities.

\section{CONCLUSION}

It was found that different heat pretreatments of MMT seeds significantly affected the oil yield, free fatty acid value, DPPH radical scavenging activity, total phenolic content and ferric reducing antioxidant power (FRAP) $(\mathrm{p}<0.05)$. However, the seed heat pretreatment did not affect the fatty acid composition significantly ( $p>0.05)$. Among the four pretreatments, the preferable treatments were microwave and roasting. Microwave gave the highest yield and the lowest free fatty acid content, while roasting also gave the highest yield and the highest total phenolic content.

\section{ACKNOWLEDGEMENT}

The authors acknowledged that this research work was funded under Knowledge and Technology Assimilation Grant (KTAG), Universiti Malaysia Terengganu, Malaysia.

\section{REFERENCES}

Abril, D., Mirabal-Gallardo, Y., González, A., Esteban, F.D-L., Santos, L.S. \& Valdés, O. 2019. Comparison of antioxidative stability and antioxidant activity of extra-virgin olive oils and oils extracted from seeds of Colliguaya integerrima and Cynara cardunculus under normal conditions and after thermal treatment. Antioxidants (Basel), 8(10): 470.

Akoh, C.C. \& Nwosu, C.V. 1992. Fatty Acid Composition of Melon Seed Oil Lipids and Phospholipids. Journal of the American Oil Chemists' Society, 69(4): 314-316.

Aisyah Athirah, H., Muhammad Firdaus, M.H., Wahizatul Afzan, A., Wan Zaliha, W.S. 2017. Effects of different storage temperatures on physicochemical characteristics and quality of Melon Manis Terengganu (Cucumis melo var. Inodorus cv. Manis Terengganu 1). Journal of Plant Physiology, 25(1): 183-191.

Anjum, F., Anwar, F., Jamil, A. \& Iqbal, M. 2006. Microwave roasting effects on the physicochemical composition and oxidative stability of sunflower seed oil. Journal of American Oils Chemists' Society, 83: 777-784.

AOAC. 1980. Official Methods of Analysis of the Association of Official Analytical Chemistry. 13th Ed., Iodine Value. Wijs Method, 28.020.

AOAC. 2000. Official Methods of Analysis of the Association of Official Analytical Chemists, 16th ed., Arlington, Virginia, Vol. II, Ch. 41.

Azhari, S., Xu, Y.S., Jiang, Q.X. \& Xia, W.S. 2014. Physicochemical properties and chemical composition of seinat (Cucumis melo var. tibbish) and its antioxidant activity. Grasas Aceites, 65: 1-8.

Baboli, Z.M. \& Kordi, A.A.S. 2010. Characteristic and composition of watermelon seed oil and solvent extraction parameter effects. Journal of American Oil Chemist' Society, 8: 667-671.

Baogu, X., Zhang, M., Xing, C., Mothibe, K.J. \& Zhu, C. 2013. Composition, characterisation and analysis of seed oil of Sueda salsa L. Journal of Food Science and Technology, 48(4): 879-885. 
Bligh, E.G. \& Dyer, W.J. 1959. A rapid method of total lipid extraction and purification. Canadian Journal of Biochemistry and Physiology, 37(8): 911-7.

Chandrasekara, N. \& Shahidi, F. 2012. Oxidative stability of cashew oils from raw and roasted nut. Journal of American Oil Chemistry Society, 88: 1197-1202.

Chen, L., Young-Hwa, K. \& Jun-Kyu, S. 2014. Roasting processed oriental melon seed influence the triglyceride profile. Food Research International, 58: 236-242.

Codex Alimentarius Commission. 2001. Codex Alimentarius: Fats. Oils and Related Products. Volume 8. Joint FAO/WHO Codex Alimentarius Commission. Food and Agriculture Organization.

Danso-Baoteng, E. 2011. Effect of enzyme and heat pretreatment on sunflower oil recovery using aqueous and hexane extractions. International Journal of Chemical and Biological Engineering, 4(1): 28-32.

Druż yńska, B., Stepniewska, B.A. \& Wolosiak, R. 2007. The influence of time and type of solvent on efficiency of the extraction of polyphenols from green tea and antioxidant properties obtained extracts. Acta Scientiarum Polonorum, Technologia Alimentaria, 6(1): 27-36.

Đurđević, S., Milovanović, S., Šavikin, K., Ristić, M., Menković, N., Pljevljakušić, D., Petrović, S. \& Bogdanović, A. 2017. Improvement of supercritical $\mathrm{CO} 2$ and n-hexane extraction of wild growing pomegranate seed oil by microwave pretreatment. Industrial Crops and Products, 104: 21-27.

Durmaz, G. \& Gökmen, V. 2011. Changes in oxidative stability, antioxidant capacity and phytochemical composition of Pistacia terebinthus oil with roasting. Food Chemistry, 128(2): 410-414.

Górnaś, P. \& Rudzińska, M. 2016. Seeds recovered from industry by-products of nine fruit species with a high potential utility as a source of unconventional oil for biodiesel and cosmetic and pharmaceutical sectors. Industrial Crops and Products, 83: 329-338.

Gumaling, R.P., Agusan, J.R.E., Ellacer, N.V.C.R., Abi, G.M.T.A., Pajaron, J.R.P., Joyno, J.R.Q., Joyno, C.Q. \& Arazo, R.O. 2018. Increased biooil yield from Swietenia macrophylla seeds through microwave pretreatment and ultrasonicassisted solvent extraction. Sustainable Environment Research, 28(6): 430-43.

Ibrahim, S. 2016. Cucumol A: a cytotoxic triterpenoid from Cucumis melo seed. Brazillian Journal of Pharmacology, 26:701-704.
Ivanova, P.H. 2012. The melons-Raw material for food processing. In 50 years Food RDI International Scientific-Practical Conference "Food, Technologies and Health" Proceeding Book (pp. 023-026). Plovdiv, Bulgaria.

Japir, A.A-W., Salimon, J., Derawi, D., Bahadi, M., Al-Shuja'a, S. \& Usop, M.R. 2017. Physicochemical characteristics of high free fatty acid crude palm oil. OCL, 24(5): D506.

Lau, C.P., Ibrahim, N.H. \& Hayati, M.Y. 2012. Effect of pretreatments on chemical and antioxidant properties of sky fruit (Swietenia macrophylla) seed oil. Jurnal Teknologi dan Industri Pangan, 23(2): 205.

Lee, Y-C, Oh, S-W., Chang, J. \& Kim, I-H. 2004. Chemical composition and oxidative stability of safflower oil prepared from safflower seed roasted with different temperatures. Food Chemistry, 84(1): 1-6.

Mallek-Ayadi, S., Bahloul, N. \& Kechaou, N. 2018. Phytochemical profile, nutraceutical potential and functional properties of Cucumis melo L. seeds. Journal of the Science of Food and Agriculture, 99: 1294-1301.

Mallek-Ayadi, S., Bahloul, N. \& Kechaou, N. 2019. Cucumis melo L. seeds as a promising source of oil naturally rich in biologically active substances: compositional characteristics, phenolic compounds and thermal properties. Grasas Aceites, 70(1): e284.

Marina, A.M., Che Man, Y.B., Nazimah, S.A.H. \& Amin, I. 2008. Antioxidant capacity and phenolic acids of virgin coconut oil. International Journal of Food Sciences and Nutrition, 60: 114-123.

Mazaheri, Y., Torbati, M., Azadmard-Damirchi, S. \& Savage, G.P. 2019. Effect of roasting and microwave pretreatment of Nigellla sativa L. seeds on lipase activity and the quality of oil. Food Chemistry, 88: 480-486.

Milind, P. \& Kulwant, S. 2011. Musk melon is eatmust melon. International Research Journal of Pharmacy, 2(8): 52-57.

Mariod, A.A., Ahmed, Y.M., Matthaus, B., Khaleel, G., Siddig, A., Gabra, A.M. \& Siddig Ibrahim Abdelwahab. 2009. A comparative study of the properties of six Sudanese cucurbit seeds and seed oils. Journal of American Oil Chemists Society, 86(12): 1181-1188.

Moussata, C.O. \& Akoh, C.C. 1998. Influence of lipase-catalyzed interesterification on the oxidative stability of melon seed oil triacylglycerols. Food Chemistry, 75(9): 11551159. 
Muhammad, N., Sahadan, W. \& Ho, L.H. 2018. Effect of drying temperatures and extraction solvents on total phenolic, flavonoid contents and antioxidant properties of immature Manis Terengganu Melon (Cucumis melo). Journal of Agrobiotechnology, 9(1S): 114-121.

Nyam, K.L., Tan, C.P., Che Man, Y.B., Lai, O.I. \& Long, K. 2009a. Physichochemical properties of Kalahari melon seed oil following extraction using solvent and aqueous enzymatic methods. International Journal of Food Science and Technology, 44: 694-701.

Nyam, K.L., Tan, C.P., Lai, O.M., Long, K. \& Che Man, Y.B. 2009b. Physicochemical properties and bioactive compound of selected seed oil. LWT - Food Science and Technology, 42(8): 1396-1403.

O'Brien, R. 2004. Fat and Oil: Formulation and Processing for Application, Technology Publishing, Lancester, PA.

Olubi, O., Felix-Minnaar, J.V. \& Jideani, A.V. 2019. Physicochemical and fatty acid profile of egusi oil from supercritical carbon dioxide extraction. Heliyon, 5(1): e01083.

Onyeka, U., Onuegbu, N., Onuoha, N.U., Ochonogor, F. \& Ochonogor, F. 2005. Effect of extraction pretreatment on the composition and characteristic of seed and pulp oil of African black pear. Nigerian Food Journal, 23(1): 13-20.

Oomah, B.D., Liang, J., Godfrey, D. \& Mazza, G. 1998. Mirowave Heating of Grapeseed: Effect on Oil Quality. Journal of Agriculture and Food Chemistry, 46: 4017-4021.

Peiretti, P.G., Meineri, G., Gai, F., Longato, E. \& Amarowicz, R. 2017. Antioxidative activities and phenolic compounds of pumpkin (Cucurbita pepo) seed and amaranth grain extract. Natural Product Research, 31(18): 2178-2182.

Petkova, Z. \& Antova, G. 2015. Proximate composition of seed and seeds oil from melon cultivated in Bulgaria. Cogent Food \& Agriculture, 1: 1018779.

Petkova, Z. \& Antova, G. 2019. A comparative study on quality parameters of pumpkin, melon and sunflower oils during thermal treatment. $O C L$, 26: 32 .

Potoènik, T., Magda, R.C. \& Košir, I.J. 2018. Influence of seed roasting on pumpkin seed oil tocopherols, phenolics and antiradical activity. Journal of Food Composition and Analysis, 69: 7-12.
Ramanadhan, B. 2005. Microwave extraction of essential oils (from black pepper and coriander) at $2.46 \mathrm{Ghz}$, Canada: University of Saskatchewan, MSc thesis.

Shimada, K., Fujikawa, K., Yahara, K. \& Nakamura, K. 1992. Antioxidative properties of xanthan on the autoxidation of soybean oil in cyclodextrin emulsion. Journal of Agricultural and Food Chemistry, 40(6): 945-948.

Silva, M.A., Albuquerque, T.G., Alves, R.C., Oliveira, M.B.P.P. \& Costa, H.S. 2019. Melon seeds oil, fruit seeds oil and vegetable oils: a comparison study. Annals of Medicine, 51: sup1, 166.

Silva, M.R., Moraes, E.A., Lenquiste, S.A., Godoy, A.T., Eberlin, M.N. \& Maróstica, M.R., Jr. 2014. Chemical characterization and antioxidant potential of Chilean chia seeds and oil (Salvia hispanica L.). LWT - Food Science and Technology, 59: 1304-1310.

Timms, R.E. 1978. Artefact peaks in the preparation and gas liquid chromatographic determination of methyl esters. Australian Journal of Dairy Technology, 33(1): 4-6.

Uquiche, E., Jeréz, M. \& Ortiz, J. 2008. Effect of pretreatment with microwaves on mechanical extraction yield and quality of vegetable oil from Chilean hazelnuts (Gevuina avellana Mol). Innovative Food Science \& Emerging Technologies, 9(4): 495-500.

Yang, M., Zheng, C., Zhou, Q., Liu, C., Li, W. \& Huang, F. 2014. Influence of microwaves treatment of rapeseed on phenolic compounds and canolol content. Journal of Agricultural and Food Chemistry, 62(8): 1956-1963.

Yanty, N.A.M., Osman, A., Long, K. \& Ghazali, H.M. 2008. Physicochemical properties of Cucumis melo var Inodorus (Honeydew melon) seed and seed oil. Journal of Food Lipid, 15(1): 42-55.

Zeb, A. 2016. Phenolic profile and antioxidant activity of melon (Cucumis melo L.) seeds from Pakistan. Foods, 5: 67-74.

Zhao, T., Hong, S.I., Lee, J., Lee, J.S. \& Kim, I.H. 2012. Impact of roasting on the chemical composition and oxidative stability of Perilla oil. Journal of Food Science, 77(12): C1273C1278.

Zhong, J., Wang, Y., Yang, R., Liu, X., Yang, Q. \& Qin, X. 2018. The application of ultrasound and microwave to increase oil extraction from Moringa oleifera seed, Journal of Industrial Crops and Products, 120: 1-10. 